\title{
Modulation of Physiologic Parameters in Molted Isa Brown Laying-Hens by Glutamine + Glutamic Acid Supplementation
}

\section{-Author(s)}

\section{Morales W \\ Rodríguez $\mathrm{V}^{\prime,}$}

Garcia NV!,II

Poultry Research group, Faculty of Veterinary Medicine, University of Tolima.

" Immunobiology and Pathogenesis Research Group, Faculty of Veterinary Medicine, University of Tolima, Altos de Santa Helena, Ibague, Colombia

\section{ABSTRACT}

Feed costs are the main limiting factors in poultry industry and alternative sources of food and/or feed supplements to optimize the bird's life cycle and to extend their production period need to be explored. This study evaluated morphometric parameters of the small intestine and gonadotropin transcript levels in Isa Brown laying hens supplemented with glutamine + glutamic acid (Aminogut $\circledast$ ) during a second production cycle. Molting was induced and groups of 100 hens each, were supplemented with $0,0.8,1.6$ or $2.4 \%$ Aminogut $\circledast$ in their diet. At the end of the experimental period, tissue sections from duodenum, jejunum and ileum were processed by the HematoxylinEosin technique and samples from hypothalamus and hypophysis were collected for RT-PCR analysis of GnRH and GnRHR transcript levels. As results, the height of the intestinal villi of the duodenum and ileum was significantly $(p<0.05)$ higher in hens supplemented with $0.8 \%$ and $1.6 \%$ Aminogut ${ }^{\circledR}$, while in the jejunum, no significant differences were found. Hens treated with increased doses of Aminogut $\circledast$ tended to increase GnRH transcripts levels, whereas those of GnRHR tended to decrease proportionally. It is concluded that supplementation of Isa Brown laying hens during a second production cycle with Aminogut $\circledast$ developed increased villus height in duodenum and ileum that may promote better absorption of nutrients and potentially to increase the egg production. This study shows the importance of molecular techniques such as RT-PCR to support the biological effects of nutritional compounds on morphological parameters and hen productivity.

\section{INTRODUCTION}

Induced molting is a strategy used to reduce the costs of egg production, allowing a second productive laying cycle that usually generates additional income without the pressure to replace and introduce new hens (Webster, 2000; Bell, 2003; Park et al., 2004). Induced molting, however, causes severe atrophy of hen tissues, particularly those of the reproductive organs and the intestinal absorptive mucosa that may limit hen productivity (Landers et al., 2008; Gordon et al., 2009; Mazzuco et al., 2011). Feed supplementation with glutamine is known to favor rapid recovery of the intestinal tissue by providing an energy source for epithelial cells (Neu et al., 1996), and it also promotes the development of the intestinal mucosa by increasing the number of cells and the size of the intestinal villus (Maiorka, 2004; Bartell \& Batal, 2006; Maiorka et al., 2016). Thus, glutamine and glutamic acid may be useful to promote better intestinal integrity and functionality, which together with the bird immunity establishes the intestinal health status of the birds and the absorptive capacity (Maiorka, 2004; Sakamoto et al., 2006; Zaravise et al., 2011), that may finally be translated into a greater hen productivity. 
Glutamine is physiologically synthesized in adequate amounts by animals; however, it is a conditionally essential amino acid that needs to be supplied in the diet when the utilization rates are increased relative to the rate of synthesis (Neuet al., 1996; Newsholme, 2001). Increased use of glutamine may include the hypercatabolic stages induced by weaning (Teixeira et al, 2014), injury by fasting, infection or disease, oxidation and damage by endotoxins (Yi et al., 2005; Ayazi, 2014; Mayorga, 2013). Therefore, supplementation with glutamine and glutamic acid might be necessary for a rapid tissue recovery of hens after molting.

The gonadotrophins releasing hormone $(\mathrm{GnRH})$ secretion in the hypothalamus occurs through the stimulation of Glutamic acid (main excitatory neurotransmitter in the central nervous system) on Glutamic acid receptors in hypothalamic neurons such as the GnRH-secreting GT1-7 cells (Orrego \& Villanueva, 1993; Gómez-Torres et al., 2014). Synthesis of glutamine in neurons occurs in a Glutaminasedependent manner, this biosynthesis reestablishes the normal intra-hipotalamic Glutamine levels that are related to GnRH secreting pulses (Bourguignon et al., 1995), necessary to induce the release of gonadotropic hormones, follicle stimulation (FSH) and luteinizing hormone (LH), responsible for gonadal maturation and steroidogenesis in the hypophysis (Prieto \& Velázquez, 2002). Laying hens supplemented with $0.8 \%$ glutamine improved productive parameters, the structure of duodenum and oviduct, and increased blood levels of luteinizing hormone ( $\mathrm{LH})$, follicle stimulating hormone (FSH), triiodothyronine (T3) and tetraiodothironine (T4) hormones (Xiao Ying et al., 2010). In addition, Glutamine supplemented chickens improved feed efficiency and morphology of the small intestine after parasite challenge (Yi et al., 2005; Sakamoto et al., 2014; Luquetti et al, 2015). Glutamine improved body-weight gain, feed conversion and immune response in chickens (Bartell \& Batal 2006; Soltan, 2009). Glutamine also increased the length of villi in duodenum and jejunum of 7, 14 and 21 day-old chicks (Bartell \& Batal, 2006). These studies suggest that supplementation of birds with glutamine and glutamic acid constitutes a strategy to improve bird productivity.

We hypothesized that glutamine may have an effect on the development of intestinal morphology and on the levels of $\mathrm{GnRH}$ and GnRHR gene expression of molted hens. To begin to test this hypothesis, molting was induced in ISA Brown laying hens and transcriptional changes in GnRH and GnRHR were evaluated by RT-PCR together with the intestinal morphology after glutamine + glutamic acid (Aminogut $\circledast$ ) supplementation.

\section{MATERIALS AND METHODS}

\section{Location}

The study was conducted at San Carlos poultry farm, located 5 kilometers far from the municipality of San Pedro de los Milagros, department of Antioquia, Colombia. This region is located 2,475 $\mathrm{m}$ above sea level and an average temperature of $14^{\circ} \mathrm{C}$. Histologic processing and molecular techniques were performed in the laboratory of Veterinary Pathology and the Laboratory Immunology and Molecular Biology, University of Tolima. Experimentation with live animals was approved by the bioethics committee of the University of Tolima.

\section{Experimental animals and diets}

A total of 400 Isa Brown laying hens were selected for having an average weight between 1900-2000g at the end of its first production cycle. Hens were grouped (4 birds $\times$ cage) in 100 California type wire cages with water supply and mesh floor, suitable for feeding and maintenance of the laying hens.

A completely randomized experimental design with three percentages $(0.8,1.6$ and $2.4 \%)$ of Aminogut ${ }^{\circledR}$ and a control free-product diet were applied to 100 birds per group. The commercial product Aminogut $\AA$ (Ajinomoto Interamericana) is an association of glutamine (Gln) + glutamic acid (Glu) at a concentration of $10 \%$ and was used according to the manufacturer's specifications. The diets were prepared at the Field Food Plant and formulated based on corn and soybean meal, according to the nutritional requirements of laying hens (Rostagno et al., 2011).

The completely randomized design consisted of 20 birds per experimental unit, with 5 replicates and 100 hens per treatment. Each cage has 4 birds and 5 cages of 4 birds constituted an experimental unit. Ten (10) randomly selected hens from those cages of each treatment were used for the collection of the tissue samples at 119 days of the experiment, since at this time it was assumed that the hens were at peak of egg production.

\section{Intestinal morphometric analysis}

A random sample of ten birds per treatment were collected after 119 days of production and then electrically stunned to be unsensitized before sacrificed by exsanguination. Duodenal samples from the pylorus to the distal portion of the duodenal loop; jejunum from the distal duodenal loop to Meckels diverticulum and ileum from Meckels diverticulum to the ileocecal union were obtained, washed in saline and fixed in 
$10 \%$ buffered formalin. Fixed tissues were embedded in paraffin and processed by Hematoxylin-Eosin $(\mathrm{H}$ \& E) technique, as described previously (Becak \& Paulete, 1976). Serial $5 \mu \mathrm{m}$ thick tissue sections were mounted on microscope slides and stained with HematoxylinEosin. The height and width of intestinal villi, depth of crypts and the thickness of the muscle wall were measured in at least 10 villi from each intestinal tissue section. The images were captured with an Olympus CX31 light microscope integrated with a 580 5.0MP Moticam digital camera and the images processed by a Motic Images Plus 2.0 software.

\section{Total RNA extraction from laying-hen tissues}

Total RNA from hypothalamus and hypophysis was extracted by using the Trizol@ method. Briefly, tissue samples from each hen were collected and suspended in $600 \mu \mathrm{L}$ of Trizol $\circledast$ reagent (Invitrogen Life Technologies, Inc., Carlsbad, CA, USA), and homogenized by using a syringe coupled to a 21 gauge needle until a complete cell suspension was obtained. Chloroform (150 $\mu \mathrm{L}$ ) was added and the solution was mixed vigorously, followed by 5 minutes incubation at room temperature. The tubes were centrifuged at $12,500 \mathrm{rpm}$ at $4{ }^{\circ} \mathrm{C}$ and the resultant supernatant was collected into a new Eppendorf tube. Total nucleic acids in each sample were precipitated by adding an equal volume of 2-propanol and incubated at $-20{ }^{\circ} \mathrm{C}$ for $1 \mathrm{hr}$. The samples were centrifuged at $12,500 \mathrm{rpm}$ and the nucleic acid pellet washed twice with $75 \%$ cold ethanol. The tubes were dried at room temperature and then the pellet suspended into $50 \mu \mathrm{L}$ RNase free water. RNA samples were quantified using NanoDrop 2000 (ThermoScientific Inc, USA) UV-Vis spectrophotometer and frozen at $-20^{\circ} \mathrm{C}$ until use.

\section{RT-PCR}

Five $\mu \mathrm{g}$ of total RNA was reverse transcribed into cDNA using SuperScript III RNase-reverse transcriptase (Invitrogen Life Technologies, Inc., Carlsbad, CA, USA) in accordance with the manufacturer's instructions. Briefly, $1 \mu \mathrm{l}$ of oligo $(\mathrm{dT})_{18}$ primer $(200 \mathrm{ng}), 5 \mu \mathrm{g}$ of total RNA, $1 \mu \mathrm{l}$ of $10 \mathrm{mM}$ dNTP mix, and $13 \mu \mathrm{l}$ sterile distilled water were mixed and heated at $65{ }^{\circ} \mathrm{C}$ for 5 minutes. Then, $4 \mu$ of $5 x$ first-strand buffer, $1 \mu$ l of $0.1 \mathrm{M} \mathrm{DTT}, 1 \mu \mathrm{l}$ of RNase inhibitor and $200 \mathrm{U}$ of SuperScript III RT were added and incubated at $50^{\circ} \mathrm{C}$ for $50 \mathrm{~min}$. The reaction was inactivated by heating at $70{ }^{\circ} \mathrm{C}$ for $15 \mathrm{~min}$, and diluted 1:5 with distilled water. A total of $2 \mu \mathrm{l}$ of cDNA (first strand) was used as a template for amplification of 202 bp of $\mathrm{GnRH}$ transcript from hypothalamus by using the forward 5'-GCTTGGCTCAACACTGGTCT-3' and reverse 5'CTGGCTTCTCCTTCGATCAG-3' primers described by $\mathrm{Ni}$ et al., (2013), and amplification of 417 bp of GnRHR transcript from hypophysis was conducted by using the forward 5'- GGTGTCTGAGGCTCATTTCA-3'and reverse 5'-TAGCAATCGCTTGCCCAGA-3' primers described previously (Dunn et al., 2004). The PCR conditions included a denaturing step at $94{ }^{\circ} \mathrm{C}$ for 3 minutes, 35 cycles of PCR that included adenaturation at $94{ }^{\circ} \mathrm{C}$ for $30 \mathrm{~s}$, annealing at $55^{\circ} \mathrm{C}$ for $30 \mathrm{~s}$, and extension at $72{ }^{\circ} \mathrm{C}$ for $30 \mathrm{~s}$ and a final extension step at $72^{\circ} \mathrm{C}$ for $7 \mathrm{~min}$. Amplification of $299 \mathrm{bp}$ of $\beta$-actin control transcript was conducted by using the forward 5'- TGCGTGACATCAAGGAGAGAAG.3' and reverse 5'-TGCCAGGGTACATTGTGGTA-3' primers described by Ni et al. (2013). The PCR products were mixed with $10 \times$ loading buffer and then resolved by electrophoresis on $2 \%$ agarose gel with 100 bp DNA ladder (Applied Biological Materials ABM Inc.). The gel was stained with ethidium bromide and visualized under the UV light by using an ENDURO TM GDS (Labnet International, Inc) Gel documentation system.

\section{Statistical analysis}

A completely randomized design was performed with four treatments, each one with five replicates and 20 birds per replicate, for a total of 100 birds per treatment and 400 birds for the total of the experiment. The analysis of variance (ANOVA) was used to determine the differences between treatments; the $F$ value and the significant or highly significant results $(p<0.05)$ were applied to the Duncan multiple range test to establish differences between them. Statistical analyzes were performed using the SPSS software version 2.0.

\section{RESULTS AND DISCUSSION}

This study shows for the first time that morphometric analyses of the small intestine of Isa Brown laying hens in the second production cycle supplemented with Aminogut $₫$, revealed significant changes in the height and width of the villi, crypt depth and thickness of the muscle layers, this compound provides glutamic acid and glutamine, amino acids known to promote the development of the intestinal mucosa (Maiorka, 2004; Sakamoto et al, 2011; Maiorka et al., 2016).

In the duodenum, the animals supplemented with 0.8 and $1.6 \%$ Aminogut ${ }^{\circledR}$ (T2 and $\mathrm{T} 3$ ) showed the highest values in villus height compared to control (T1) and $2.4 \%$ Aminogut $\circledast$ (T4) groups. Birds supplemented 
with $0.8 \%$ Aminogut $\AA$ showed an average of 135.3 $\mu \mathrm{m}$ wide of the villi (Table 1; Figure 1A, 1B), which was not significantly different from the control group (132.25 $\mu \mathrm{m})$, however significantly higher than the width of the villi in T3 and T4 $(p<0.05)$ groups, suggesting an inverse relationship between the width of the duodenum villi and the level of Aminogut ${ }^{\circledR}$.

In this regard, Xiao Ying et al (2010) demonstrated that supplementation of laying hens with $0.8 \%$ glutamine during the first cycle improved duodenum and led to the longest height $(876.35 \mu \mathrm{m})$, and villus surface area that may improve the nutrient's absorption. The values of villus height in Isa Brown hens during the second cycle suggest that this parameter consistently increased with the age of the animals and that the

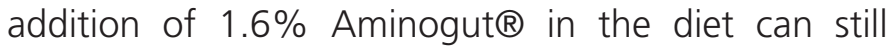
increase this parameter to values not reported in the scientific literature of laying hens during the first cycle. Trophic agents such as glutamine and glutamic acid stimulate the development of the intestinal mucosa and promote the mitotic process in the crypt-villus region and promote an increase in the number of enterocytes (Maiorka et al., 2002), the size of villus and the available surface for nutrient absorption (Dibner \& Richards, 2004; Mayorga, 2013). The duodenum is the most developed intestinal segment in relation to other segments, the great development is attributed to the fact that it has a rapid cell renewal and it is also the first segment of the small intestine to receive the chemical, physical and hormonal stimulation caused by the presence of food in the intestinal lumen (Uni et al., 1999; Kondo, 2003; Macari, 1998; Murakami et al., 2007).

Table 1 - Morphometric parameters in duodenum of laying hens at 119 days of a second cycle supplemented with different levels of Aminogut $\AA$.

\begin{tabular}{lcccc}
\hline Parameter $(\mu \mathrm{m})$ & \multicolumn{4}{c}{ Experimental Groups } \\
\hline & T1 & T2 & T3 & T4 \\
\hline Villi height & $1343 \mathrm{~A}^{*}$ & $1542 \mathrm{~B}$ & $1585 \mathrm{~B}$ & $1517 \mathrm{~B}$ \\
Villi width & $132.27 \mathrm{~B}$ & $135.3 \mathrm{~B}$ & $119.6 \mathrm{~A}$ & $120.99 \mathrm{~A}$ \\
Depth of crypt & $190.45 \mathrm{C}$ & $179.32 \mathrm{C}$ & $160.97 \mathrm{~B}$ & $143.83 \mathrm{~A}$ \\
\hline Thickness of muscle layer & $243.99 \mathrm{C}$ & $242.39 \mathrm{C}$ & $200.06 \mathrm{~B}$ & $165.48 \mathrm{~A}$ \\
\hline T1: control; T2: $0.8 \% ;$ T3: 1.6\%; T4: $2.4 \%$. & & & \\
${ }^{*}$ Different letters indicate significant $(p \leq 0,05)$ & differences.
\end{tabular}

Laying hens supplemented with $0.8 \%$ Aminogut $\circledast$ (T2) showed an average of $135.3 \mu \mathrm{m}$ villi wide in duodenum(Table 1), which wasnotsignificantly different from the control group (132.25 $\mu \mathrm{m})$. Interestingly, groups with $1.6 \%$ and $2.4 \%$ of Aminogut $\AA$ had a significant reduction in the width of the villi $(p<0.05)$, suggesting an inverse relationship between the width of the villi and glutamine + glutamic acid at higher levels (>1.6\%), as showed for villi height. Our result differ slightly from those obtained by Xiao Ying et al (2010), whom found no significant differences in the width of the villi $(131.15$ and $132.03 \mu \mathrm{m})$ in first cycle laying hens.

The depth of the villus crypt in the duodenum presented a similar change, compared to the width; while the control group recorded the maximum value of $190 \mu \mathrm{m}$, which was not significantly different from the $0.8 \%$ Aminogut $\AA$ treated group, there were significant differences compared to $1.6 \%$ and $2.4 \%$ treated groups, showing a significant reduction in the depth of the crypt $(143.83 \mu \mathrm{m})$ in animals treated with higher levels of glutamine + glutamic acid. These results contrast with those reported by Maiorka et al (2016), who found no significant difference in the depth of the crypt in broilers supplemented with 1 $\%$ glutamine $(170 \mu \mathrm{m}$ vs $168 \mu \mathrm{m})$. Sakamoto et al (2014) found that the depth of the crypt of the villi in 1 to 7 day-old Broilers ranged between 197 and $225.5 \mu \mathrm{m}$, values that are superior to those recorded in this study. The lack of data in laying hens impedes to make appropriate comparisons, however, the results of this study suggest that Aminogut $₫$ might reduce the depth of the crypt in duodenum and the availability of glutamine and glutamic acid in hens of second cycle may stimulate a higher rate of replication and renewal of stem cells at the base of the crypt that could explain the increased villus height. Another possibility is that those amino acids have an effect on survival of epithelial cells, prolonging their half-life and displaying increased villus height.

By analyzing the depth of the crypt, a similar situation was found where the control group had the highest value $(190 \mu \mathrm{m})$, and a progressive significant reduction in this parameter was observed in animals treated with increasing levels of Aminogut $₫$ (Table 1). The greatest reduction in crypt depth (143.83 $\mu \mathrm{m})$ was found in birds from the T4 group, although there were no significant differences between the $0.8 \%$ Aminogut $\circledast$ and the control group, significant differences between the groups treated with $1.6 \%$ and $2.4 \%$ Aminogut $\circledast$ and the control group were found. Finally, the thickness of the muscle layer in the control group showed $243.99 \mu \mathrm{m}$, which was similar to those found in the $0.8 \%$ Aminogut $₫$ group, however this parameter was significantly reduced $(p \leq 0.05)$ in hens treated with $1.6 \%(200.06 \mu \mathrm{m})$ and $2.4 \%(165.48$ $\mu \mathrm{m})$ Aminogut $\circledast$. 

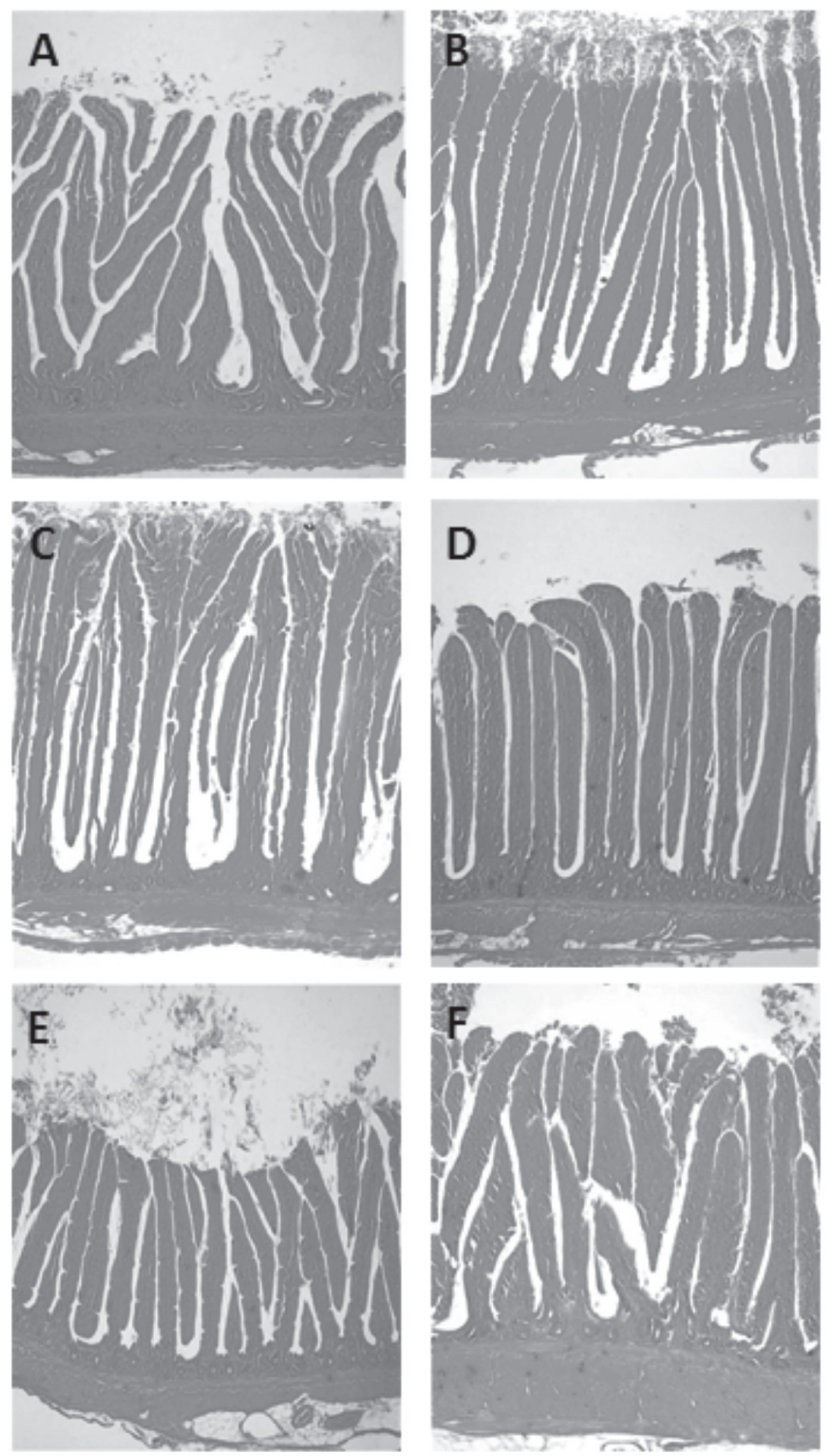

Figure 1 - Effect of glutamic acid + glutamine (Aminogut $\circledast$ ) on some morphometric parameters of the small intestine in Isa Brown laying hens at 119 days of second productive cycle. Representative microphotographs of intestinal villi of duodenum of laying hens fed $0 \%(A)$ and 1,6\% Aminogut ${ }^{\circledR}$ (B); Jejunum of laying hens fed $0 \%$ (C) and 1,6 \& Aminogut ${ }^{\circledR}(D)$; lleon of laying hens fed $0 \%$ (E) and 1,6\% Aminogut ${ }^{\circledR}(F)$. Magnification $40 \times$. H\&E.

Laying hens supplemented with Aminogut $₫$ showed a significant reduction $(p<0.05)$ in villus height, crypt depth and thickness of the muscular layer in the jejunum (Table 2; Figure 1C, 1D). The group treated with $0.8 \%$ Aminogut ${ }^{\circledR}$ presented the lowest values in villus height $(1055,93 \mu \mathrm{m})$, and width $(107.13 \mu \mathrm{m})$ versus the control group $(1212,78 \mu \mathrm{m}$ and $109.09 \mu \mathrm{m}$, respectively). Finally, in this segment of the intestine there were no differences in the width of the villi among all treatments. Similarly, Lopes \& Mogica (2008) reported a decrease in villus height in 21 day-old Broilers supplemented with $1 \%$ glutamine (758 $\mu \mathrm{m}$ vs. $748 \mu \mathrm{m}$, respectively), while Maiorka et al.
(2000) observed an increase in villus height $(546 \mu \mathrm{m}$ vs. $595 \mu \mathrm{m})$ in 7 day-old Broilers supplemented with $1 \%$ glutamine. Regarding the depth of the crypts in the jejunum of hens supplemented with Aminogut $\AA_{\text {, }}$ a significant reduction $(p<0.05)$ was observed (Table 2) compared to the hens in the control group. These results contrast with those reported by Lopes \& Mogica (2008), who found no differences in the depth of the crypt of birds supplemented with $1 \%$ glutamine compared to the control group (73 vs. $73 \mu \mathrm{m}$ ). On the other hand, Maiorka et al. (2000) reported an increase in crypt depth (96 vs. $84 \mu \mathrm{m}$ ) in the jejunum of birds supplemented with $1 \%$ glutamine vs. the control group. The differences in mean values between studies might reflect differences in breeds of hens or perhaps in tissue processing that need to be improved in future studies.

Table 2 - Morphometric parameters in Jejunum of laying hens at 119 days of a second cycle supplemented with different levels of Aminogut $\circledast$.

Parameter $(\mu \mathrm{m})$

\begin{tabular}{lcccc}
\hline \multicolumn{5}{c}{ Experimental Groups } \\
\hline & T1 & T2 & T3 & T4 \\
Villi height & 1212.78 B & $1055.93 \mathrm{~A}$ & $1102.87 \mathrm{~A}$ & $1058.06 \mathrm{~A}$ \\
Villi width & $109.09 \mathrm{~A}$ & $107.13 \mathrm{~A}$ & $112.44 \mathrm{~A}$ & $110.66 \mathrm{~A}$ \\
Depth of crypt & $160.68 \mathrm{~B}$ & $142.99 \mathrm{~A}$ & $158.97 \mathrm{~B}$ & $132.04 \mathrm{~A}$ \\
Thickness of muscle layer & $262.96 \mathrm{C}$ & $221.28 \mathrm{~B}$ & $232.01 \mathrm{~B}$ & $191.14 \mathrm{~A}$ \\
\hline T1: Control; T2: 0.8\%; T3: 1.6\%; T4: $2.4 \%$ & & & \\
*Different letters indicate significant $(p \leq 0.05)$ differences. & &
\end{tabular}

Laying hens supplemented with 0.8 and 1.6\% Aminogut $₫$ had a median villus in lleum height of $804.51 \mu \mathrm{m}$ and $783.35 \mu \mathrm{m}$, respectively (Table 3; Figure $1 \mathrm{E}, 1 \mathrm{~F})$, which was not significantly different from the villus height of control group $(741.45 \mu \mathrm{m})$, while birds treated with $2.4 \%$ Aminogut $₫$ showed the lowest values in this parameter (541.24 $\mu \mathrm{m})$. Regarding to the width of the villi, the birds treated with $0.8 \%$ Aminogut ${ }^{\circledR}$ showed the highest values $(113.71 \mu \mathrm{m})$, being significantly different $(p<0.05)$ from the control group $(98.97 \mu \mathrm{m})$. The group treated with $2.4 \%$ Aminogut $($ showed the lowest values in this parameter $(84.76 \mu \mathrm{m})$, which was also significantly different $(p<0.05)$ from the control group. When analyzing the crypt depth, groups treated with $0.8 \%$ and $1.6 \%$ of Aminogut $\AA$ showed the highest values (106.86 and $142.57 \mu \mathrm{m})$ respectively, compared to the control group $(89.19 \mu \mathrm{m})$. Finally, the thickness of the muscle layers was significantly reduced $(p<0.05)$ in the groups treated with $0.8 \%$ and $1.6 \%$ Aminogut $\AA$ (184.14and $198.33 \mu \mathrm{m})$ respectively, versus the control group $(229.95 \mu \mathrm{m})$, whereas the $2.4 \%$ Aminogut@ treated 
group showed no significant differences compared to the control group. Similar results were reported by Lopes \& Mogica (2008), in birds supplemented with $1 \%$ glutamine (748 versus $758 \mu \mathrm{m})$, respectively, and by Xiao Ying et al (2010) in laying hens of first cycle and by Sakamoto et al. (2014) in male Cobb Vantress ${ }^{\circledR}$ Broilers. Contrary to what was reported by Maiorka et al. (2000) and Lopes \& Mogica (2008), the results of this study may indicate that supplementation of Isa Brown laying hens with $0.8 \%$ and $1.6 \%$ Aminogut $®$ during the second cycle may stimulates increased height and width of villi and crypt depth in the ileum, whereas higher levels of the compound (2.4\%) would have a deleterious effect on this section of the small intestine. Additional studies are needed to clarify those morphological changes induced by Aminogut $\circledast$ in ISA Brown laying hens.

The thickness of muscle layers in ileum was significantly reduced $(p<0.05)$ in hens supplemented with $0.8 \%$ and $1.6 \%$ Aminogut $\circledast(184,14 \mu \mathrm{m}$ and $198.33 \mu \mathrm{m})$, respectively, versus the control group $(229.95 \mu \mathrm{m})$, whereas the thickness in the $2.4 \%$ Aminogut ${ }^{\circledR}$ treated group was not significantly different from the control group. These results contrast with those reported by Xiao Ying et al (2010), who documented little variation in the thickness of the muscle layers (145 and $148 \mu \mathrm{m}$ ) in hens of first cycle, however, the reasons for these differences are presently unknown and it is necessary to take into account the variations in body-weight of the hens (1900- $2000 \mathrm{~g}$ ) and the individual behavior of animals.

Table 3 - Morphometric parameters in ĺleum of laying hens at 119 days of a second cycle supplemented with different levels of Aminogut $\circledast$.

\begin{tabular}{lcccc}
\hline Parameter $(\mu \mathrm{m})$ & \multicolumn{5}{c}{ Experimental Groups } \\
\hline & T1 & T2 & T3 & T4 \\
Villi height & $741.45 \mathrm{~B}$ & $804.51 \mathrm{~B}$ & $783.35 \mathrm{~B}$ & $541.24 \mathrm{~A}$ \\
Villi width & $98.97 \mathrm{~B}$ & $113.71 \mathrm{C}$ & $103.97 \mathrm{BC}$ & $84.76 \mathrm{~A}$ \\
Depth of crypt & $89.19 \mathrm{~A}$ & $106.86 \mathrm{~B}$ & $142.57 \mathrm{C}$ & $85.16 \mathrm{~A}$ \\
Thickness of muscle layer & $229.95 \mathrm{C}$ & $184.14 \mathrm{~A}$ & $198.33 \mathrm{AB}$ & $224.78 \mathrm{BC}$ \\
\hline
\end{tabular}

T1: Control; T2: 0.8\%; T3: 1.6\%; T4: $2.4 \%$.

*Different letters indicate significant $(p \leq 0.05)$ differences.

This study shows that Isa Brown laying hens during the second cycle has an average height of the villi of the duodenum, jejunum and ileum of 1343, 1212, and $741 \mu \mathrm{m}$, respectively, which are higher than those recorded in hens during the first productive cycle (Xiao Ying et al., 2010), and those parameters could be modulated by Aminogut $\AA$ supplementation. It was reported that 34 week-old laying hens supplemented with Aminogut $\AA$ improved the intestinal duodenal structure (Xiao Ying et al., 2010), and that glutamine increased the development of intestinal villus in 7- dayold broiler chicks (Sakamoto et al., 2014; Maiorka et al., 2016). However, to our knowledge the effects of glutamine + glutamic acid provided by Aminogut $\circledast$ supplementation in laying hens of second cycle had not been previously reported.

To begin to understand the relationship between glutamine and glutamic acid on the synthesis and expression of reproductive hormones that control hen productivity, RT-PCR analysis was conducted on tissue samples from hypothalamus and hypophysis of hens

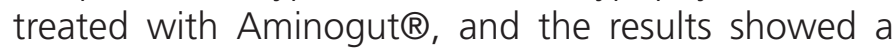
trend of increasing the GnRh transcripts when the levels of Aminogut $\circledast$ augmented in the diet (Figure 2). The increase in GnRh transcript was observed in hens from $\mathrm{T} 2$ and $\mathrm{T} 3$, and less prominent in hens from T4. Contrary to what was observed in hypothalamus, analysis of tissue samples from the hypophysis showed that the receptor GnRhR transcript levels reduced proportionally in hens treated with Aminogut $₫$, and this reduction was prominent in birds treated with 2.4\% Aminogut@ (Figure 3).

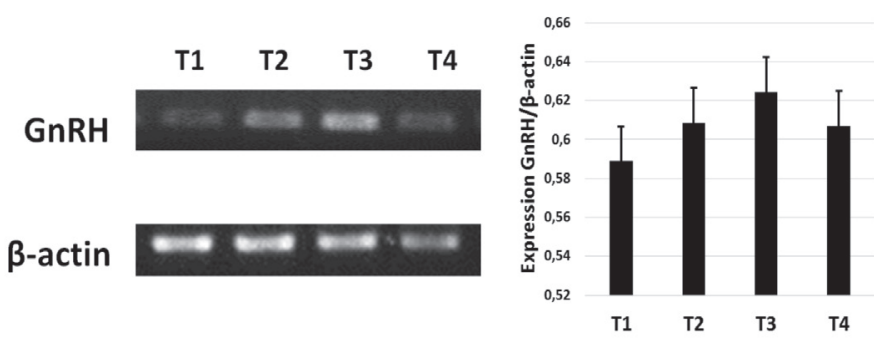

Figure 2 - RT-PCR analysis of gonadotropin releasing hormone (GnRh) from hypothalamus of laying hens supplemented with glutamine + glutamic acid. Left panel: representative gel showing a PCR amplification product of $202 \mathrm{bp}$ of the GnRh transcript. Right panel: semi-quantitative analysis of the GnRh transcript expression levels regarding to the $\beta$-actin expression.
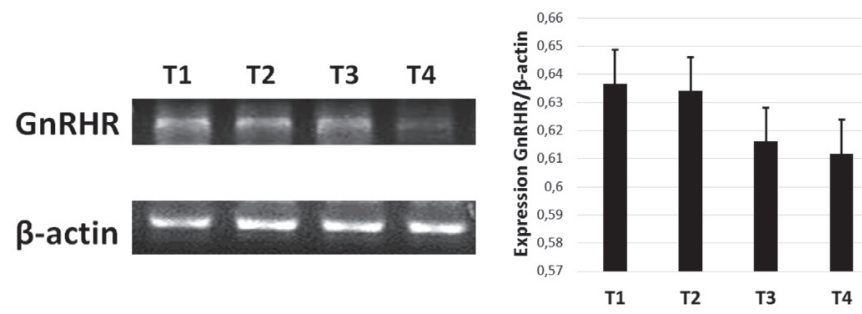

Figure 3 - RT-PCR analysis of gonadotropin releasing hormone receptor (GnRhR) from hypophysis of laying hens supplemented with glutamine + glutamic acid. Left panel: representative gel showing a PCR amplification product of 417 bp of the GnRhR transcript from hens of each experimental group. Right panel: semi-quantitative analysis of the GnRhR transcript expression levels regarding the $\beta$-actin expression.

The changes observed in GnRh may suggest that those amino acids may induce increased gonadotropinreleasing hormone transcription and probably at the protein level, the transcription levels of the receptor 
GnRhR indicates that the increased GnRh production might be counterbalanced by a reduction in the levels of the receptor and might suggest the presence of a physiological limit in cell activation/response in target cells of the adenohypophysis. The results might also stress the importance of maintaining a homeostatic balance between hormone and receptor stimulation. Additional studies are needed to evaluate whether those changes in GnRhR transcription observed in the hypophysis have significant effects on $\mathrm{FSH} / \mathrm{LH}$ transcription.

In conclusion, supplementation of Isa Brown laying hens with $0.8 \%$ and $1.6 \%$ glutamine + glutamic acid (Aminogut $₫$ ) during the second production cycle, stimulated the development of villus height in the duodenum and ileum, and those changes may increase the absorptive surface of the small intestinal mucosa. Aminogut $\circledast$ treatment may also have an effect on $\mathrm{GnRh}$ and GnRhR transcript levels that should be translated into increased pulses of gonadotropin hormones and egg production, however modulation of GnRhR transcripts may constitute a regulatory mechanism to maintain physiologic parameters of hens within homeostasis. Additional analysis is needed to clarify the effects on gene transcription at different time points as well as in other physiological and biochemical parameters.

\section{ACKNOWLEDGMENTS}

The authors thank the Central Research Office of the University of Tolima for funding this research (Project No. 250114) and the director of the San Carlos Poultry Company and other member of the Poultry Research Group that participated in this study.

\section{REFERENCES}

Ayazi M. The effect of dietary Glutamine supplementation on performance and blood antioxidant status of broiler chickens under continuos heat stress condition. International Journal of Farming and Allied Sciences 2014;3(12):1213-1219.

Bartell SM, Batal AB. The effect of supplemental glutamine on growth performance, development of the gastrointestinal tract, and humoral immuneresponse of broilers. Poultry Science 2006;86:1940-194.

Becak W Paulete J. Citology and histology techniques. Rio de Janeiro: Scientific and Technical Books Editora; 1976.

Bell DD. Historical and current molting practice in the U.S. table egg industry. Poultry Science 2003;82:965-970.

Dibner J. The digestive system: challenges and opportunities. Poultry Science Association 2004;13:86-93.

Gordon R, Bryant M, Roland DA. Performance and profitability of second cycle laying hens as influenced by body weight and body weight reduction during molt. Journal of Applied Poultry Research 2009;18:223-231.
Kondo N. Estudo das características morfometricas de diferentes regiones do Intestino delgado e índices zootécnicos em quatro linhagens de frangos de corte [tese]. Botucatu (SP): Universidade Estadual Paulista; 2003

Landers K. Evaluation of the use of alfalfa diets as an alternative to feed deprivation for the induction of molt in comeercial laying eggs [thesis]. College Station (TX): A \& M University; 2008

Lopes KL, Mogica NS. Suplementacao de glutamina em dietas inicias para frangos de corte [tese]. Goiânia (GO): Universidad federal de Goias; 2008

Luquetti BC, Fernandez MF, Lunedo R, Borges D, Furlan RL, Macari M. Effects ofglutamine of performance and intestinal mucosa morphometry of broiler chickens vaccinated against coccidiosis. Scientia Agricola 2015;73(4):322-327.

Macari M. Aspectos fisiológicos do sistema digestivo das aves. Anais da 8 SACAVET, Semana Académica Medicina Veterinaria;1998; São Paulo, SP. Brasil. p.4-18.

Maiorka A, Fischer da Silva AV, Santin E, Borges AS, Boleli IC, Macari $M$. Influence of glutamine supplementation on performance and development of villi and crypts of the small intestine of chickens. Arquivo Brasileiro de Medicina Veterinaria e Zootecnia 2000;52(5):487490.

Maiorka A, et al. Desenvolvimento e reparo da mucosa intestinal. In: Macari M, Furlan R.L, Gonzales, E. Fisiología aviária aplicada a frangos de corte. Jaboticabal: FUNEP/UNESP; 2002. p.113-123.

Maiorka A. Impacto da saude intestinal na produtividade avícola. Anais do $5^{\circ}$ Simposio Brasil de Avicultura; 2004; Chapecó, Santa Catarina. Brasil: Universidade Federal do Paraná; 2004.

Maiorka A, Silva AVF, Santin E, Dahlke F, Bruno LDG, Boleli IC, et al. Effect of broiler breeder age and glutamine supplementation on the development of the intestinal mucosa of 7- day - old chicks. Brazilian Journal of Poultry Science 2016;18:17-22.

Mayorga ME. Glutamina y salud intestinal de monogastricos. Revista Plumazos 2013;46:4-12.

Murakami AE, Sakamoto MI, Natali RMN, Souza LMG, Franco JRG. Supplementation of glutamine and vitamin $\mathrm{E}$ on the morphometry of the intestinal mucosa in broiler chickens. Poultry Science 2007;86:488495

Mazzuco H, Avila VS, Coldebella A, Mores R, Jaenisch FRF, Lopes LS. Comparison of the effect of different methods of molt: production and welfare valuation. Poultry Science 2011;90:2913-2920.

Neu J, Shenoy V, Chakrabarti R. Glutamine nutrition and metabolism: where do we go from here? The FASEB Journal 1996;10:829-837.

Newsholme P. Glutamine metabolism: nutritional and clinical significance. American Society for Nutritional Science 2001;131:2515-2522.

Ni Y, Lv J; Wang S, Zhao R. Sexual maduration in hens is not associated with increase in serum leptin and the expression of leptin receptor mRNA in hypothalamus. Journal of Animal Science and Biotechnology 2013;4:24.

Park S, Kim W, Birkhold L, Kubena,L, Nisbet D, Rickel. Induced moulting issue an alternative dietary strategies for the egg industry in the United States. Department of Poultry Science, Texas A \&M University. World's Poultry Science Journal 2004;60.

Rostagno H, Teixeira LF, Lopes J, Gomes PC, Oliveira RF, Lopes DC, et al. Tablas brasileñas para aves y cerdos. Viçosa (MG): Universidade Federal de Viçosa, Departamento de Zootecnia; 2011 
Sakamoto MI, Murakami AE, Silveira TGV, Fernandes JIM, Oliveira CAL de. Influence of glutamine and vitamina $E$ on performance and the inmune responses of Broiler chickens. Brazilian Journal of Poultry Science 2006;8(4):243-249.

Sakamoto MI, Faria DE, Nakagy VS, Negrao JA, Araujo RB, Souza KMR, et al. Utilization of glutamine associated with glutamic acid, on development and enzymatic activity in Broiler chickens. Brazilian Journal Poultry Science 2011;63(4):962-972

Sakamoto MI, Faria DE, Nakagy VS, Murakami AE. Sources of trophic action onperformance and intestinal morphometry of broiler chickens vaccinated against. Revista Brasileira de Ciencia Avícola 2014;16:389396.

Soltan MA. Influence of dietary glutamine supplementation on growth performance, small intestinal morphology, immune response and some blood parameters of broiler chickens.international Journal of Poultry Science 2009;8(1):60-68.

Teixeira A, Nogueira E, Kutschenko N, Rostagno HS, Lopes DC. Inclusion of glutamine associated with glutamic acid in the diet of piglets weanes at 21 days of age. Revista Brasileira de Saúde e Produção Animal 2014;15(4):881-896
Uni Z, Gal-Galbert O, Geira A, Sklan D, Yahav S. Changes in growth and function of chick small intestine epithelium due to early termal conditioning. Poultry Science 2001;80:438-445.

Webster, AB. Behavior of white leghorn layings hens after withdrawal of feed. Poultry Science 2000;79:192-200

Xiao-Ying D, Chu-Fen Y, Sheng-Qui T,Qing -Yan J, Xiao-Ting Z .Effect and mechanism of glutamine on productive performance and egg quality of laying hens. Asian-Australasian Journal of Animal Sciences 2010;23(8):1049-1056

Yi FG, Allee GL, Knight CD, Dibner JJ. Impact of Glutamine and Oasis hatchling Supplement on growth performance, small intestinal morphology, and immuneresponse of broilers vaccinated and challenged with Eimeria máxima. Poultry Science 2005;84(2):283-293.

Zavarize KC, Sartori JR, Pelicia VC, Pezzato AC, Araujo PC, Stradiotti AC, et al. Glutamine and nucleotides in the diet of broiler chickens raisein the alternative system. Archivos de Zootecnia 2011;60(232):913-920. 